\title{
The Sustainability Route to Corporate Legitimacy
}

Jennifer Hutchins, jhutch35@kennesaw.edu

Mona Sinha, msinha1@kennesaw.edu

\begin{abstract}
The world has limited resources and these are depleting exponentially due to accelerated consumption. Ecosystems, environment, economies and even the planet are under threat. Pushback from communities and governments is forcing companies to recognize the necessity of creating shared value (Porter \& Kramer, 2011) and along with this has come the realization that it is possible to 'do well by doing good' (Sisodia, Wolfe, \& Sheth, 2007). Such shared value would help firms earn corporate legitimacy. Legitimacy is broadly defined as "a generalized perception or assumption that the actions of an entity are desirable, proper, or appropriate within some socially constructed system of norms, values, beliefs and definitions" (Suchman, 1995). Legitimacy from external groups or individuals is an essential resource (Dowling \& Pfeffer, 1975; Suchman, 1995). It adds to reputational capital (Bansal \& Clelland, 2004) by conforming to the institutional expectations of stakeholders that include numerous internal and external constituencies who can affect or be affected by the achievement of an organization's objectives such as, employees, customers, supply chain members, investors, partners/other companies etc.
\end{abstract}

One way of gaining such legitimacy is by pursuing sustainability goals for balancing the expectations of multiple stakeholders. Indeed, sustainability addresses the needs of people and the planet while also being profitable for the company - a concept also referred to as the triple bottom line (Elkington, 1999). Academic research on sustainability is relatively recent and there remain many research gaps in literature, the most significant being the lack of a coherent theoretical framework that can guide companies' efforts in this area. Consequently, practice has been leading academia in this area and examining their goals, practices and outcomes can provide insights for developing a comprehensive sustainability framework.

To pursue sustainability goals companies have to develop a stakeholder orientation (Laczniak \& Murphy, 2012) towards achieving triple bottom line objectives. Doing so will enhance their corporate reputation (Sheth \& Sinha, 2015) while also creating great brand value (Chakravorti, 2010). However, while some companies may genuinely be concerned about their stakeholders, others may do it solely for reputational purposes. Therefore, it is important to examine whether companies with intensive and/or extensive sustainability efforts would be perceived as more legitimate than others, especially as compared to those that engage in 'greenwashing,' - the act of overstating or otherwise misleading others about an organization's environmental attributes or attributes of their offerings. Firms with high corporate legitimacy are perceived as more predictable, trustworthy, and meaningful (Suchman, 1995) hence, the linkage between stakeholder orientation, corporate legitimacy and sustainability intrigues us. We propose that firms can earn legitimacy by conforming to stakeholders' institutional expectations. Our research proposes to examine how different categories of sustainability efforts reflect differing levels of corporate legitimacy and whether stakeholders recognize and value such legitimacy. We also propose to examine the effect of legitimacy on consumers' perceptions of the company.

\section{References}

Bansal, P., \& Clelland, I. (2004). Talking trash: Legitimacy, impression management, and unsystematic risk in the context of the natural environment. Academy of Management Journal, 47(1), 93-103.

Chakravorti, B. (2010). Stakeholder Marketing 2.0. Journal of Public Policy \& Marketing, 29(1), 97-102.

Dowling, J., \& Pfeffer, J. (1975). Organizational legitimacy: Social values and organizational behavior. Pacific Sociological Review, 122-136.

Elkington, J. (1999). Cannibals with Forks: The Triple Bottom Line of 21st Century Business. Oxford. 
Laczniak, G. R., \& Murphy, P. E. (2012). Stakeholder Theory and Marketing: Moving from a Firm-Centric to a Societal Perspective. Journal of Public Policy \& Marketing, 31(2), 284-292.

Porter, M. E., \& Kramer, M. E. (2011). The Big Idea: Creating Shared Value. Harvard Businerr Review, 89(1/2), 62-77.

Sheth, J. N., \& Sinha, M. (2015). B2B Branding in Emerging Markets: A Sustainability Perspective. Industrial Marketing Management, 51(November), 79-88.

Sisodia, R. S., Wolfe, D. B., \& Sheth, J. N. (2007). Firms of Endearment: How World-Class Companies Profit from Passion and Purpose. FT Press.

Suchman, M. C. (1995). Managing Legitimacy: Strategic and Institutional Approaches. Academy of Management review, 20(3), 571-610.

Keywords: stakeholders, corporate legitimacy, sustainability

\section{Author Information:}

Jennifer Hutchins is Assistant Professor in the Department of Marketing and Professional Sales at Kennesaw State University. She hold a Ph.D. from the University of Memphis. She teaches Advertising and Promotion and is an active researcher in the area of stakeholders, corporate social responsibility, and sustainability.

Mona Sinha is Assistant Professor in the Department of Marketing and Professional Sales at Kennesaw State University. She hold a Ph.D. from Texas A\&M University and, was a post-doctoral research fellow at Emory University. She teaches International Marketing and her research is on sustainability, emerging markets and social justice.

Relevance to Marketing Educators, Researchers and Practitioners: To provide (1) a theoretical framework aligning research on stakeholder and corporate legitimacy, and (2) guidelines to companies undertaking sustainability initiatives for assessing impact and alignment with goals.

\section{Track: Green Marketing/Sustainability}

